\title{
Environmental Awareness: Environmental Accidents as an Example to be Avoided. A Summative International Analysis
}

\author{
Christos Giannoulis ${ }^{1,2}$, Constantina Skanavis ${ }^{1}, \&$ Evgenia Karapatsiou ${ }^{1}$ \\ ${ }^{1}$ School of Environment. Department of Environment. University of the Aegean, Lesvos Island, Greece \\ ${ }^{2}$ College of Science, Department of Education and Interdisciplinary Studies. Florida Institute of Technology, Melbourne, \\ Florida, USA
}

Correspondence: Constantina Skanavis, School of Environment. Department of Environment. University of the Aegean, Lesvos Island. University Hill. 81100. Mytilene, Lesvos Island, Greece.

Received: February 4, 2014 Accepted: February 26, 2014 Available online: March 11, 2014

doi:10.11114/smc.v2i1.334

URL: http://dx.doi.org/10.11114/smc.v2i1.334

\begin{abstract}
The wealth of environmental problems, plaguing us globally, requires special attention, largely due to the frequent indifference of citizens in the environmental decision-making process. Young people, as the future generation of decision makers, should receive proper education to prevent further environmental degradation. A summative international analysis of how the media framed when reporting man-made environmental disaster news has been conducted. Our aim is to provide an evaluation of the media's role in the dissemination of information related to national and international environmental regulations, disaster responses, and the legalities surrounding compensation and recovery of the ones affected. A literature review and surveillance of news response and reporting related to environmental accidents' disasters was conducted, starting from the 1950s. A number of notable trends were identified. News response and coverage were upgraded as years went by. The diversity of news, the number of stories, the consequences' awareness and the use of social media services in disaster response, all showed a growing tendency as far as promotion of responsible environmental behavior through the media news, around the globe. Investing further on media communication and engagement during and after environmental accidents, as well as in building a strong environmental interest, seems to be the way to have resilient communities.
\end{abstract}

Keywords: environmental accidents, environmental awareness, environmental communication, environmental education

\section{Context and Overview}

The agenda-setting theory, in 1968, gave rise to more than 400 studies which examined the capacity of the mass media to frame debates' influence of public opinion (McCombs 2005). Most of the studies relied on fundamental postulates: first, that the media's essential function is not simply to transmit facts, but to filter them in an interpretive sense. Selecting and composing illustrative or explanatory narratives from a wide range of possible interpretations that lay within uncategorized data is a task heavily placed on the media's environmental agenda.

How rapidly, with what urgency, and for how long media reports on events, serves as an implicit indicator of their perceived importance of the selected events. Media are the ones that need to place high in their agenda setting, their environmental communication role, because of their unique power to elicit public response.

Over the course of the last 200 years, the relationship between humans and their natural environment has experienced a profound and ongoing transformation. Awareness of this transformation has expanded since the late eighteenth century, when studies of flooding and erosion patterns in the Alps by Fabre, Surrell, and Horace-Benedict served to "immeasurably" deepens the realization that humans have an increasing--and increasingly dangerous--capacity to alter the environment that historically dictated even the smallest details of human existence (Goudie 2013).

Crutzen and Stoermer (2000) have suggested that the human impacts on the environment are substantial enough to mark the beginning of a new geological epoch, the anthropocene, the birth of which is often considered to coincide with the onset of the Industrial Revolution. This concept has received growing scientific recognition (Lövbrand, et al 2009) as well as growing media recognition (Boycoff 2009). 
Environmental sustainability has introduced a variety of issues, which range from environmental accidents and natural disasters to food availability, justice, racism and poverty. The human hope is that by balancing available technology with social transformation, our race will ultimately achieve a peaceful and prosperous Earth.

Specifically, the relationship between people and the environment has long been utilized as an important context for the study of environmental accidents. The related concerns focus on how human behavior can adapt to and cope with new situations before, during, and after an environmental disaster. Catastrophes all over the world, with high-impact events, have repeatedly underlined the environmentally destructive power human actions hold.

Indeed, many of these worrying environmental trends result from structural features of contemporary human approaches to production and industry; as such, they are chronic issues. The wealth of environmental problems plaguing us globally requires special attention, largely due to the frequent indifference of citizens in the environmental decision-making process. Young people, as the future generation of decision makers, should receive proper education to prevent further environmental degradation.

While the media has played an admirable role in educating the public about environmental issues and problems, the post-9/11 period, the global economic crisis and the nature itself of news reporting is, perhaps, less-than-suited to generating and maintaining interest in issues that seem to jeopardize life in the immediate future.

The purpose of the current study is to identify patterns that disasters related to environmental accidents are framed by the news media. A survey of the major newsworthy environmental accidents, since the mid-1950's, was conducted. The nature of the damage caused--which is to say, whether human lives were lost, and the impact on local flora and fauna, was recorded. The survey was backed up by the review of some of the available information on related communities' response to the respected disasters.

Three major illustrative disasters' responses were illustrated because of the unique way they were reported in the media. The aim is to identify trends in the field of journalism, when dealing with environmental accidents, and determine environmental education needs.

\section{Overview of Large-Scale Trends with Respect to Man-Caused Environmental Disasters}

The present study focuses on 48 environmental accidents, starting with the mercury contamination of Minamata Bay in 1956 and ending with the Fukushima nuclear meltdown and the ongoing war-related pollution in Afghanistan. Oil spills, explosions in industrial plants, chemical spills, air pollution accidents, nuclear accidents, war consequences of war are seen in Table 1. There is no doubt that when the effects of accidents become widely known, no one wishes to become another statistic. Around the globe, technological innovations are accountable for the great accomplishments seen in medicine and transportation. At the same time, horrible accidents have been experienced on industrial scales, whether because of human error, systems malfunctions, or some combination thereof. The effects of these catastrophes often transcend geographic borders; thus, we have adopted an international approach to our analysis.

Of the disasters examined, 21 resulted in the loss of human life, while seven documented only significant impacts on local wildlife (Table 1).

Only three events-- the industrial accidents at Piper Alpha Gas and Petroleum in 1988, Philips Petroleum in 1989, and Longford Gas in 1998--did not register significant impacts on the natural environment. All three though resulted in human deaths (Table 1).

Smith (2013, pp. 373) notes that although "technology is the cause of some environmental problems, it can also help clean up pollution from accidental spills. No wonder that there is no universally agreed-upon definition of a "technological hazard".

Glickman, Golding, and Silverman illustrate this point nicely:

Since the end of World War II, over 1,200 natural disasters have claimed the lives of more than 2.3 million people around the world, and caused widespread damages and severe economic losses. [...] Since 1945, almost 300 major industrial accidents have claimed the lives of 15,000 people. (1992: 1).

If we assume that there can be a crisp division between these events, then in the period from 1945-1986, natural disasters occurred with a frequency of approximately 30 per year, and major industrial accidents at about 7 per year. The annual worldwide death-tolls from these accidents have tended to parallel the number of people that died in highway accidents each year over this period, or about 56,000 annual fatalities (Glickman, Golding, Silverman, 1992: 1). 
Table 1. Historical Review of man-made environmental disasters.

\begin{tabular}{|c|c|c|c|c|c|}
\hline Year & Year & Continent/Region & $\begin{array}{l}\text { Human } \\
\text { lives-death }\end{array}$ & $\begin{array}{l}\text { Natural } \\
\text { impact }\end{array}$ & $\begin{array}{l}\text { Impact on } \\
\text { Wild Life }\end{array}$ \\
\hline \multicolumn{6}{|l|}{ Industrial } \\
\hline Seveso chemical & 1976 & Europe (Italy) & $\mathrm{X}$ & $\mathrm{X}$ & \\
\hline Bhopal chemical & 1984 & India & $X$ & $\mathrm{X}$ & \\
\hline Sandoz chemical & 1986 & Europe- (Switzerland) & & $\mathrm{X}$ & \\
\hline Piper Alpha gas and petroleum & 1988 & Europe (North Sea) & $\mathrm{X}$ & & \\
\hline Phillips Petroleum & $\begin{array}{c}1989,1999 \\
2000\end{array}$ & N. America (Texas) & $\mathrm{X}$ & & \\
\hline Longford gas & 1998 & Australia (Victoria) & $X$ & & \\
\hline Jilin chemical plant & 2005 & China & $\mathrm{X}$ & $\mathrm{X}$ & \\
\hline \multicolumn{6}{|l|}{ Accidents due to war } \\
\hline Kuwait & 1991 & Middle East- Kuweit & & $\mathrm{X}$ & \\
\hline New York City - Terror Attack & 2001 & N.America US (NY) & $X$ & $X$ & \\
\hline Afghanistan war pollution & $\begin{array}{l}\text { 2001-till } \\
\text { now }\end{array}$ & Afghanistan & $\mathrm{X}$ & $\mathrm{X}$ & \\
\hline \multicolumn{6}{|l|}{ Oil Spills } \\
\hline Wafra & 1971 & Africa (Cape Agulhas) & & $\mathrm{X}$ & \\
\hline Amoco Cadiz & 1976 & Europe (France) & & $\mathrm{X}$ & $\mathrm{X}$ \\
\hline Niger Delta & 1976 & Africa (Niger Delta) & & $X$ & \\
\hline Ixtoc I & 1979 & N. America (Mexico) & & $\mathrm{X}$ & $\mathrm{X}$ \\
\hline Castillo de Bellver & 1983 & Africa (Castillo de Bellver) & & $\mathrm{X}$ & \\
\hline Odyssey & 1988 & N. America (Canada) & & $\mathrm{X}$ & \\
\hline Exxon Valdez & 1989 & N. America (Alaska) & & $\mathrm{X}$ & \\
\hline Bosporus Strait & 1994 & Southwest Asia (Middle East) & & $\mathrm{X}$ & \\
\hline Apollo Sea & 1994 & Africa (Apollo Sea) & & $\mathrm{X}$ & \\
\hline Erika & 1999 & Europe (France) & & $\mathrm{X}$ & $\mathrm{X}$ \\
\hline Prestige & 2002 & Europe (Spain) & & $\mathrm{X}$ & \\
\hline Tricolor & 2002 & Europe-Mediterranean & & $\mathrm{X}$ & $\mathrm{X}$ \\
\hline Sea Diamond & 2007 & Europe (Greece) & & $\mathrm{X}$ & \\
\hline Russian spills & 2007 & Russia (Moscow) & $\mathrm{X}$ & $\mathrm{X}$ & \\
\hline Hebei Spirit & 2007 & Asia (S.Korea) & & $\mathrm{X}$ & \\
\hline Queensland Container Ship & 2009 & Australia-(Queensland) & & $\mathrm{X}$ & \\
\hline Great Barrier Reef & 2010 & Australia (Great Barrier Reef-Victoria) & & $\mathrm{X}$ & \\
\hline Deepwater Horizon & 2010 & N. America (Gulf of Mexico) & $\mathrm{X}$ & $\mathrm{X}$ & $\mathrm{X}$ \\
\hline Negev & 2011 & Middle East (Israel) & & $\mathrm{X}$ & $\mathrm{X}$ \\
\hline Shell & 2011 & Europe (North Sea) & & $\mathrm{X}$ & $\mathrm{X}$ \\
\hline Chevron & 2011 & S. America (Brazil) & & $\mathrm{X}$ & \\
\hline \multicolumn{6}{|l|}{ Chemical Spills } \\
\hline Minamata Bay & 1956 & Asia (Far East, Japan) & $\mathrm{X}$ & $\mathrm{X}$ & \\
\hline Love Canal & 1978 & N. America (Niagara Falls) & $\mathrm{X}$ & $\mathrm{X}$ & \\
\hline Windsor-Mississauga Train Derailment & 1979 & N. America (Ontario, Canada) & & $\mathrm{X}$ & \\
\hline Marcopper & 1996 & Asia (Far East, Philippines) & $X$ & $X$ & \\
\hline Waste Water & 1998 & Europe (Spain) & & $\mathrm{X}$ & \\
\hline Baia Mare (Aurul) & 2000 & Europe (Hungary) & & $\mathrm{X}$ & \\
\hline Guangxi Cadmium & 2012 & Asia (Far East, China) & & $\mathrm{X}$ & \\
\hline \multicolumn{6}{|l|}{ Nuclear Accidents } \\
\hline Chernobyl & 1986 & Europe (Ex-Sovietic Union, Ukraine) & $\mathrm{X}$ & $\mathrm{X}$ & \\
\hline JCO Co., Ltd & 1999 & Asia (Far East, Japan) & $\mathrm{X}$ & $\mathrm{X}$ & \\
\hline Fukushima & 2011 & Asia (Far East, Japan) & $\mathrm{X}$ & $\mathrm{X}$ & \\
\hline \multicolumn{6}{|l|}{ Accidents due to human actions } \\
\hline Bitter & $1958-1961$ & Asia (Far East, China) & $\mathrm{X}$ & $\mathrm{X}$ & \\
\hline Methyl & 1970 & Asia (Middle East, Iraq) & $\mathrm{X}$ & $\mathrm{X}$ & \\
\hline Aral Sea & 2010 & Central Asia & & $\mathrm{X}$ & \\
\hline Paraguay & 2011 & S. America (Paraguay) & $\mathrm{X}$ & $\mathrm{X}$ & \\
\hline \multicolumn{6}{|l|}{ Air pollution accidents } \\
\hline Donora Death Fog & 1948 & N. America (Donora, USA) & $\mathrm{X}$ & $\mathrm{X}$ & \\
\hline London smog disaster & $1952-1953$ & Europe (England) & $\mathrm{X}$ & $\mathrm{X}$ & \\
\hline Bellevue Hazardous Waste Fire & 2001 & Australia (Bellevue) & & $\mathrm{X}$ & \\
\hline
\end{tabular}


For a number of reasons, researchers have long been interested in studying the marginalized communities that are typically mostly affected by environmental catastrophes--communities whose social vulnerability and limited coping capacity often contribute to making environmental accidents so devastating. Interestingly, according to Fraser et al. (2003), the population that impacts a given ecological system and the population that experiences the impact are often very different, and as a result are inclined to divergent recovery strategies: after all there are a range of possible responses to environmental hazards, and communities may initiate very different responses to these threats, and adaptation processes can vary tremendously. This wide variance is exacerbated by the fact that these events take place on ecological timescales: the full ecological response to disruption could take years to studying the impact of catastrophes on the vulnerable and economically disadvantaged also led researchers to the concept of "resilience" one which has become increasingly attractive in recent years. In some sense, this concept was normative, and even aspirational, based on the hope that a framework could be developed, that would allow responders to manage vulnerable populations, both during and after unforeseeable disasters.

This challenge is a daunting one: after all, affected locations and their populations need not only to bounce back after disasters, but bounce forward as well--and fast. In other words, there is a pressure not only to recover from a given catastrophe and its range of comorbidities, but to implement policies that can provide some measure of protection against future disasters.

Thus, the notion of resilience touches on the interaction between acute social stress and rapid ecological change. In short, it has to do with the responsive elasticity of an affected socio-ecological system: how well a given system can rebound and transform after a shock.

In more concrete terms, resilience is often defined as a measure of the persistence of systems and their ability to absorb disturbance without dramatically altering existing relationships between populations and state variables (Holling 1973). Alternate definitions emphasize maintenance of structure and function post-shock (Walker and Salt, 2006)--or, in the terminology of Folk et al. (2010), persistence of identity.

According to Carpenter et al. (2001), resilience is composed of several simple characteristics: the amount of disturbance a system can absorb and still remain within the same state or domain of attraction; the degree to which the system is capable of self-organization; and the ability to build and increase the capacity for learning and adaptation.

It is this final characteristic that is so crucial to our current exploration: after all, in modern societies, the media is the primary channel for the dissemination of information about past and current catastrophes. Thus, access to the educational and up-to-date information carried by media sources--and the paradigm employed by the media as it discusses catastrophes--is a crucial determinant of a group's overall resilience.

It is important to note that resilience contrasts sharply with the idea of vulnerability, or the extent to which a system is vulnerable to harm as a result of changing conditions. Instead, it is more closely related to the concept of sustainability, or the capacity of a system to adapt to gradual change (Berkes et al 2003). In simple terms, these concepts deal with the impact people can have on their environment, and their subsequent ability to absorb the aftereffects of the very change they impose.

However, it is important to examine the categories of resilience. Dovers \& Handner (1992) address the distinct differences between reactive and proactive resilience. Reactive resilience is associated with adaptive capacity, the ability to implement strategies to manage hazards during and after the event. Proactive resilience, on the other hand, denotes the uniquely human capacity to anticipate and learn. ${ }^{1}$

Thus, media and communications infrastructure is a fundamental instrument in promoting both expressions of resilience. Communicators transmit expert advice to those who need it most--alerting, informing, motivating, and mobilizing public action on both emergent and preventative policy actions. They provide information, empowering people to act sustainably and drum up support for relevant public policy (Uzzell, 2004; Vlek and Steg, 2004). A clear understanding of the habits, barriers, identities, and pragmatic support needs, as well as institutions, laws, and social norms that constrain or facilitate certain behaviors, must accompany every effort that seeks to use communication in support of individual and collective behavior change (Moser and Dilling, 2007). Environmental policies are, usually, poorly understood by stakeholders. This limits the policies' application in conditions of heightened vulnerability, reduced resilience, and poor adaptation.

The risks--and the need for efficient channels of information flow--could not be greater. According to Smith:

Environmental hazards pose important--even growing--threats which are rarely capable of simple solutions. Complex on-going processes--globalization, climate change, population

1 Note that resilience should not be equated with invulnerability. 
growth, resource depletion, increasing material wealth--influence the death and destruction that disaster brings. This applies to all nations, although it is the poorest countries, and the most disadvantaged people, who suffer most. [...] Over the years, the information highway leading to hazards and disasters has become increasingly congested (2013).

Indeed, this congestion is reflected in our own analysis. Source material--whether journalistic or scholarly in nature--is rather sparse for the earlier events reviewed, becoming increasingly plentiful as we approach the present. Social media, internet and technological innovations that have made friendly to the average citizen the capturing of images and recording of sound as well as uploading to internet sites these data have served to blur the line between bystanders and journalists.

\section{Environmental Awareness, Man-Made Disasters, and the Role of the Media}

In an effort to explore how the news media have framed prior environmental disasters, two of the most well known environmental accidents would be presented.

\subsection{The "Minamata Disease" Incident}

Though most accounts trace this man-made disaster to 1956 (the year "Minimata disease" was first identified and characterized), in actuality it began to take shape almost two decades earlier, in 1932. It was in that year that a chemical plant owned by the Chisso Corporation began dumping a synthetic waste product, methyl mercury, in the nearby Minimata Bay. This product--which is highly toxic to a range of organisms--underwent simultaneous and complementary processes of bioaccummulation and biomagnification. The first process simply implies that sea life--some of which were used by residents as a primary food source--absorbed methyl mercury faster than they could dispose of it. The second process adds to this effect: even as the toxin accumulates at higher trophic levels, it is magnified as predators ingest contaminated prey (EPA 1997). As this chemical accumulated in the local human population, it gave rise to "the most massive pollution problem to strike Japan in the post-Second World War Period." (Large 1998: 206).

In 1959, three years after the problem was identified by a medical research team, local residents and fishermen rioted in their quest for compensation. It was at this juncture that the Japanese news media made its entrance, and the broader Japanese populace became aware of the issue. "If this action had not been taken by the fishermen," writes Jun (1992), "the Minimata disease would never have become national news."

Even so, chemical dumping continued for nearly another decade--and the legal battles lasted far beyond that. News organizations in the United States gave attention to this catastrophe in the mid-1970's, particularly in response to a series of photographic essays by the celebrated American photographer W. Eugene Smith (Jenks 2011).

This lack of interest may seem shocking to the contemporary reader. In the early stages, one might be tempted to attribute this to a high degree of uncertainty or apathy to whatever didn't sell as a story, that's probably why it was publicized when the riot--the social conflict narrative-emerged as an attractive opportunity.

\subsection{The Bhopal Toxic Gas-Leak Crisis}

This is known as a gas leak at a Union Carbide pesticide plant that immediately killed over 2,250 people, with final confirmed tolls tolls approaching 4,000. Some scholars estimate that the real number may be quadruple the confirmed figure. The leak caused over 550,00 injuries due to gas exposure. Even today, it is widely considered to be the single worst industrial disasters in human history (Jenks 2011; Eckerman, 2005).

The first report on the tragedy appeared on the front page of The Hindu.

The story was 1,500 words long, and cited "at least 350" deaths. According to The Hindu's retrospective on its coverage:

The lead story provides comprehensive information related to the calamity — the treatment of the injured at different hospitals, the arrival of the Central Bureau of Investigation team, the house arrest of five senior officers of Union Carbide, the appointment of an inquiry committee, and the disruption of traffic. All that is expected in a report on a calamity is there in the report.

But although informative, the first report somehow fails to convey the enormity of the event, possibly because it looks like a patchwork of agency items. The supportive box has a lot of information on methyl isocyanate. A front page report carried an announcement that Prime Minister Rajiv Gandhi had released Rs. 40 lakh for rehabilitation of the affected people. (Viswanathan 2010)

Thus, this tragedy was framed by the media as a blunt report of just describing the type, severity and people's response. 
Perhaps, though due to the severity of the situation, its drama, or even cultural factors, coverage was much more rapid, widespread, and in-depth than what we witnessed at Minimata. Interestingly, while the media chose to portray Minimata initially as a conflict narrative, The Hindu clearly chose to examine Bhopal as an act of god. The following day, a narrative of conflict is firmly established, underlining the important role the field of journalism plays.

\begin{abstract}
...the fact that the highly toxic methyl isocyanate continued to leak for nearly an hour and turned the neighborhood into a virtual gas chamber, made it clear that there had been an inexcusable failure to discharge the responsibility on the part of those engaged in an inherently hazardous activity. (Viswanathan 2010)
\end{abstract}

Subsequent editorials advocated for an investigation into the chemical industry, with particular attention to be paid to its safety procedures.

Comparing the coverage of Minimata to that of Bhopal a journalistic new approach is detected. Rather than simply seeking a "sensational" story, as was the tactic of the news media at Minimata, the coverage of the Bhopal disaster seems to have been approached with a participatory and responsible manner. Answers are being investigated to: What has happened; What emergency response existed; Who is at fault; How are we going to evaluate the likelihood of such an event happening again.

These questions seek to engage multiple narratives and the diverse interests of an apparently more knowledgeable audience. Media through their informative role, they can elicit participatory response.

\title{
3.3 The Fukushima-Daiichi Nuclear Accident
}

On 11 March, 2011, a 14 meter tsunami generated by a massive undersea earthquake surged onto Japan's eastern coastline. The damage was extensive enough to compromise emergency systems and backup power generation at the Fukushima Daiichi Nuclear Power Plant, crippling its ability to cool its reactors. As a result, multiple reactors underwent a nuclear meltdown--the largest nuclear disaster since Chernobyl, which occurred just two years after the Bhopal gas tragedy.

Examination of the two traditional forms of media--newspapers and television--reveals fairly predictable trends in news focus, closely paralleling the pattern articulated above in the coverage of Bhopal. Rausch observes, "from damage and recovery to concentration on recovery, along with a "human interest narrative' from event to victims to volunteers to local participation." She continues:

From a social science perspective, this portrayal is indicative of a newspaper fulfilling its multiple functions. One of these is the social utility function, both in terms of the quantity of information and the quality of information. This was confirmed as informants allowed that the newspaper could not be charged with accusations of hype - with regard to any aspect of the triple disaster, whether the disaster itself, the nuclear catastrophe that followed or the economic and social implications thereof. While the presence of disaster narratives was clear, these narratives, both reflected a prevailing public attitude and were judged an appropriate function of the newspaper. (2012)

Meanwhile, Lazic's content analysis of the The New York Times, The Los Angeles Times, and USA Today, highlights the challenges encountered by journalists seeking to obtain coherent, consistent, high-quality information, arguing that journalists were unable to accurately assess the situation due to disagreements among experts. Thus, Lazic argues that "the Fukushima accident was framed as a conflict of experts and officials' opinions, utility and government officials' responsibility, and economic consequences for US." (2013).

On the whole, numerous observers commended mainstream newspapers for their avoidance of sensationalist reporting, as well as for their science-based attempts to put radiation threat levels into context--even as cable news outlets were criticized for hyperbolic coverage and failing to effectively use airtime to inform their viewership of the complexities of the situation. Again, neither observation is particularly groundbreaking, although the net result is multifaceted, largely responsible, generally high-quality coverage far superior to the "abysmal" journalism afforded previous nuclear catastrophes, such as Chernobyl or Three Mile Island (Nisbet 2012).

There are, however, two crucial developments that may be observed in the coverage of this disaster. This very discussion, hints at first development: academia has become hyper aware of the critical importance of media framing with respect disaster events. The sheer quantity of scholarship covering the media's coverage of this disaster is, quite honestly, stunning: entering "Media coverage of the Fukushima Disaster" into Google Scholar returns nearly 5,000 results.

The second development, however, is even more groundbreaking: the role of the Internet and social media in 
disseminating information about disasters has revolutionized response efforts. Not only did traditional outlets capitalize on this powerful tool for rapid data exchange, citizens "actively participate in blogs and on Facebook, Twitter, and YouTube, exchanging views and directing others to important news articles or videos." (Friedman 2011). Furthermore, in locales directly affected by the earthquake, traditional media outlets were unavailable; instead, "web-enabled Smartphones became the primary devices for media access" following the earthquake.

"Media access" here denotes access to online news services as well as social networks: indeed, the line between these entities is blurring as well. Empirical studies exploring the sources and credibility of information shared in the month following the disaster indicates that Tweets with reference to third-party sources not only constituted "the bulk of the messages sent," but also that the information they provided was "highly credible." (Thompson et al. 2012).

Finally, cutting-edge research indicates that the social networking functions of these technologies can assist not only in the aftermath of a disaster, but in the moments leading up to it as well: recent studies suggest that not only do real-time networking services like Twitter generate harvestable geospatial information that can be harvested and analyzed to generate event-maps, they can even be used to detect a target event (such as an earthquake) in real-time, serving as highly reactive social sensors (Cox 2013; Stefanidis 2013; Sakaki 2010)

Clearly, these trends constitute powerful new tools enhancing the reactive resiliency of communities, as advanced communications technologies become increasingly accessible to marginalized social strata. The real task is to enhance proactive resilience by communications technologies.

Risk perception and tolerance are based on information presented to the party making the assessment. In the context of environmental risk assessment and response, information influence not only the outcome decisions, but the decision-making process as well. This information includes (but is by no means limited to) the content, level, depth, complexity, and saliency of the information, the degree to which it correlates with preconceived expectations, the extent to which environmental issues are believed to be personally threatening, the method of presentation, and the trust in the source of information, all influence people's decision making (Morgan \& Lave,1990; Nordlund \& Garvill, 2002; Folke et al., 2003; Frewer, 2001; Lubell, 2002; Seguin, Pelletier \& Hunsley, 1999).

Personal involvement is a particularly crucial factor. If information on environmental threats is perceived as personally relevant, people are more likely to adopt behavior that sustains a healthy social-ecological balance (Lubell, 2002). Environmental accidents portrayed by the media bring to light the real and complex interactions of vulnerability, adaptation and resilience on a day-to-day--and sometimes even minute-by-minute--basis. Nevertheless, communities remain vulnerable to a range of industrial and environmental threats, in large part because information from scientists and other experts is often ineffectively conveyed.

Thus, the media play a central role in disaster response and prevention. After all, they are largely responsible for dictating what is communicated and for what purpose, how this communication occurs (which is to say, through what channels and in what form), when data is transmitted, and the intended audience the information is designed to reach. Furthermore, in our modern data-rich world, the media serves a crucial function with respect to sorting fact from fiction, truth from rumor: when the New York Times says that a disaster is in progress, the warning is received differently than when an anonymous blogger makes a similar claim.

While information communicated by the media does not typically translate into policy or action, when the channels of communication are poor or nonexistent, science has little chance to enter into the decision-making process or inform action at all.

Policy relies on the public support and active participation of individuals as well as communities. However, in order to become vocal advocates for change, individuals require some working knowledge of the issues at hand. Moreover, while individual action can be either fostered or constrained by high-level policy decisions, it can also influence those decisions when empowered by access to reliable information of precisely the kind that the media apparatus is designed to provide. However, much of this communication between the scientific establishment and the general public is disseminated by the news media, and as such is subject to the political and economic imperatives of that enterprise: stories that do not "sell," for instance--whether because of a lack of drama, emotional appeal, novelty, or other interest-generating "hooks"--risk being filtered out.

Therein lies one of the most persistent challenges of public education: many scientists are not accustomed or trained to present their findings in ways that appeal to reporters. In fact, resistance to having one's academic work "sensationalized" to fit the taste of the media or the public is common.

Yet the advice and guidance of environmental and technical experts is eminently valuable in situations where it is necessary to alert, inform, motivate, mobilize, and support effective public action with respect to global environmental challenges. These problems need to be articulated in a way that makes them meaningful, relevant, and which enhances 
their social and political salience. More often than not, the people who have the most to lose in the event of an environmental calamity are the same people who require help in order to understand the causes of and solutions to many of our current environmental dangers. Communicators must - despite uncertainty - create a sense of appropriate urgency without whipping up irrational fears. Above all, they must enable and empower people to act in sustainable ways and support relevant public policy (Uzzell, 2004; Vlek and Steg, 2004).

Importantly, scientists and other communicators must avoid (or abandon) the assumption that producing better data alone will lead to logical, environmentally-friendly behaviors, or even the support of relevant policies (McKenzie-Mohr and Smith, 1999; Dietz and Stern, 2002; Gardner and Stern, 2002; Cox 2013). A clear understanding of the habits, barriers, and identities, and pragmatic support needs, as well as an understanding of institutions, laws, and social norms that constrain or facilitate social behavior and political action, must accompany any effort that seeks to use communication in support of individual and collective behavior change (Moser and Dilling, 2007).

\section{The Importance of Environmental Education}

More so than perhaps any other institution, educational systems worldwide is charged with the vital task of encouraging students to promote responsible environmental behavior, and, furthermore, of assisting them in their advocacy. Environmental education is the process by which schools encourage the development of the skills and attitudes necessary to understand and assess the complexity and evolving relationships between man, culture, and his ecological and biophysical environments.

This understanding relies on a recognition of the range and diversity of human values, as well as on the technical clarification of both new and derived environmental concepts. Environmental education also entails extensive practice in decision-making skills and the formulation of a code of conduct of each individual on the problems related to the quality of the environment (IUCN, 1970). Because of this, environmental educators are continuously in search for topics and materials capable of capturing the attention of young students and inspiring them to take action--an ongoing task that highlights the importance of the media in discussing current events and promoting groundbreaking research.

Environmental education is a multidisciplinary process and can be a transdisciplinary venture (Krasny and Dillon 2013). It must offer both cognitive skills (related to imparting both technical and theoretical knowledge) and emotional stimuli, which are concerned with the formation of values, attitudes, and--subsequently--behavior (Skanavis 2004).

Both areas can be enhanced by the study of environmental accidents and resilient thinking processes. Insofar human society has persisted through drastic social, economic, and ecological change, it has relied upon resilient socio-ecological systems to support sustainable development of resources. ${ }^{2}$ Thus, the focus of resilient thinking is on developing sustainable-growth systems capable of responding to change and disturbance.

Walker and Salt (2006) concluded that three key conceptual points should be apprehended by resilient thought processes. First, humans live and operate, virtually without exception, in social systems that are inextricably linked to the ecological systems in which they are embedded. Second, social-ecological systems are complex, highly adaptable networks that do not change in a predictive, linear, incremental fashion. Third, resilience thinking provides a framework for viewing a social-ecological network as a single interconnected system operating over many linked scales of time and space.

The ultimate challenge is focusing on how environmental communication--especially within the educational paradigm - can enhance the ability of its target audience to think resiliently. Dewey (1938) proposed, and subsequently established, a progressive education that emphasized hands-on, experiential learning techniques. Environmental accidents and community resilience programs raise engaging questions, wherein interaction, reflection, experience, and interests in community dynamics and political democracy can be brought together to yield a highly suggestive educational regime.

Educators can arrange structured, hands-on experiences, allowing students to encounter the fundamental issues associated with industrial and environmental hazards, as well as the ability to survive catastrophes and initiate recovery procedures. Such activities have the potential to facilitate students' growth and intellectual development: by way of this active-learning process, students are able to construct their own knowledge, rather than relying on traditional didactic practices. The most effective learning is often that which is natural and meaningful (Rogers 1994).

Of course, providing resources to educators is only one small role played by the media as it seeks to promote environmental consciousness: in an ideal world, all society members should possess at least a basic education in environmental awareness, including a familiarity with current issues and the key role man plays nurturing his

2 According to Folke et al (2002), sustainable development is any development with the objective of creating and maintaing prosperous social, economic, and ecological systems. 
relationship to the environment. Citizens should also possess knowledge about the impacts of human actions on the environment and be able to critically assess their responsibilities as both beneficiaries and stewards of the environment. Moreover, they should be able to acquire certain attitudes: social values emphasizing interest in environmental issues, a willingness to actively participate in protecting and improving the health of the planet. People should also have real and meaningful opportunities to acquire the skills required to solve environmental problems. Finally, when a youth is introduced to an educational program based on ecological, political, economic, social, moral, and aesthetic considerations, the program's overarching goal should be to reinforce a student's ability of assessment: each educational area should reinforce students' abilities to critically assess a range of potential choices and decide accordingly.

Following the above prescriptions would encourage the development of a sense of social responsibility and environmental stewardship, thereby highlighting the need for participation in the form of focused and informed environmental action.

Thus, if we wish to have environmentally active communities of citizens, environmental communication strategies should continue beyond the schooling years, becoming a part of the lifelong learning process. 10 years earlier Skanavis et al were concluding that "If citizens all over the world had been environmentally educated to actively participate (activating all appropriate participatory mechanisms) in the decision-making process, we wouldn't need to study the environmental disasters. Furthermore, if citizens all over were active participants in environmental issues, it is quite possible that we would have experienced fewer environmental accidents/disasters" (2005). McPhearson and Tidball (2013) applies the notion of niche from ecology to envirormental education, making the point that environmental disasters can create a niche for the implementation of new programs initiatives.

It is for precisely this reason that the current study was undertaken: man-made environmental disasters provide excellent real-life case studies of the destructive potential of actions undertaken by mankind in the name of economic development and technological progress. At first glance, such disasters can serve as examples of what not to do. With detailed historical analysis, such as the one undertaken here, however, valuable insights can be gained. Certain fundamental relationships which may not be apparent can be revealed by such explorations. The multifaceted agenda-setting and emergency response roles of the media, for instance, is inherently connected to public education in ecological stewardship--which, in turn, is related to risk tolerance, and therefore community resilience.

Through historical explorations of disasters that occur at the interface between human industry and the environment in which it occurs, young researchers offer a valuable opportunity: to experience, by way of a range of qualia, what it means to be a statistic in a disaster situation. Such an experience could encourage intellectual and emotional investment in the cause of environmental stewardship, leading to active participation and advocacy in environmental decision-making.

In conclusion, it can be stated that if citizens all over the world had been environmentally educated to actively participate (activating all appropriate participatory mechanisms) in the decision-making process, we wouldn't need to study the environmental disasters. Furthermore, if citizens all over were active participants in environmental issues, it is quite possible that we would have experienced fewer environmental accidents/disasters (Skanavis et al 2005).

\section{References}

Berkes, R., Colding. J., \& Folke, C. (2003). Navigating social-ecological systems. Building resilience for complexity and change. Cambridge: Cambridge University Press.

Boykoff, M. T. (2009). Media representational practices in the Anthropocene Era. In Uncertainties in environmental modelling and consequences for policy making (pp. 339-350). Springer Netherlands. http://dx.doi.org/10.1007/978-90-481-2636-1_15

Carpenter, S., Walker, B., Anderies, J. M., \& Abel, N. (2001). From metaphor to measurement: resilience of what to what?. Ecosystems, 4(8), 765-781. http://dx.doi.org/10.1007/s10021-001-0045-9

Cox, R. (2012). Environmental communication and the public sphere ( $3^{\text {rd }}$ Edition). Sage.

Crutzen, P. J., \& E. F. Stoermer (2000). "The Anthropocene". Global Change Newsletter, 41, 17-18.

Dewey, J. D. (1938). Experience and education. Macmillan, New York.

Dietz, T., \& Stern, P. C. (Eds.). (2002). New tools for environmental protection: education, information, and voluntary measures. National Academies Press. Washington, DC.

Dovers, S. R., \& Handmer, J. W. (1992). Uncertainty, sustainability and change. Global Environmental Change, 2(4), 262-276. http://dx.doi.org/10.1016/0959-3780(92)90044-8

Eckerman, I. (2005). The Bhopal saga: causes and consequences of the world's largest industrial disaster. Universities 
press.

EPA (U.S. Environmental Protection Agency). (1997). Mercury Study Report to Congress. Vol. IV: An Assessment of Exposure to Mercury in the United States. EPA-452/R-97-006. U.S. Environmental Protection Agency, Office of Air Quality Planning and Standards and Office of Research and Development.

Folke, C., Colding, J., \& Berkes, F. (2003). Synthesis: building resilience and adaptive capacity in social-ecological systems. in F. Berkes. J. Colding, \& C. Folke (Eds.), Navigating social-ecological systems: Building resilience for complexity and change, 352-387. Cambridge: Cambridge University Press.

Folke, C., Carpenter, S., Elmqvist, T., Gunderson, L., Holling, C. S., \& B. Walker. (2002). Resilience and Sustainable Development: Building Adaptive Capacity in a World of Transformations. Ambio, 31(5), 437-440.

Folke, C., Carpenter, S. R., Walker, B., Scheffer, M., Chapin, T., \& Rockström, J. (2010). Resilience Thinking: Integrating Resilience, Adaptability and Transformability. Ecology and Society, 15(4), 20. Retrieved from http://www.ecologyandsociety.org/vol15/iss4/art20/

Fraser, E. D., Mabee, W., \& Slaymaker, O. (2003). Mutual vulnerability, mutual dependence: The reflexive relation between human society and the environment. Global Environmental Change, 13(2), 137-144. http://dx.doi.org/10.1016/S0959-3780(03)00022-0

Frewer, L. J. (2001). Environmental risk, public trust and perceived exclusion from risk management. Research in Social Problems and Public Policy, 9, 221-248. http://dx.doi.org/10.1016/S0196-1152(01)80030-2

Friedman, S. (2011). Three mile Island, Chernobyl, and Fukushima: an analysis of traditional and new media coverage of nuclear accidents and radiation. Bulletin of the atomic scientists, 67(5) 55-85. http://dx.doi.org/10.1177/0096340211421587

Gardner, G. T., \& Stern, P. C. (2002). Environmental Problems and Human Behavior, second edition. Pearson Custom Publishing, Boston, MA.

Glickman, T. S., Golding, D., \& Silverman, E. D. (1992). Acts of god and acts of man: recent trends in natural disasters and major industrial accidents. DIANE Publishing.

Goudie, A. (2013). The human impact on the natural environment: past, present and future. ( ${ }^{\text {th }}$ Edition). Blackwell Publishing.

Holling, C. S. (1973). Resilience and stability of ecological systems. Annual Review of Ecology and Systematics, 4, 1-23. http://dx.doi.org/10.1146/annurev.es.04.110173.000245

IUCN. (1970). International Working Meeting on Environmental Education in the School Curriculum, Carson city, Nevada, USA.

Jenks, A. L. (2011). Perils of Progress: Environmental Disasters in the Twentieth Century. Prentice Hall.

Kaigo, M. (2012). Social media usage during disasters and social capital: Twitter and the Great East Japan earthquake. Keio Communication Review, 34, 19-35.

Krasny, M., \& Dillon , J. (Eds) (2013). Trading Zones in Environmental Education. Peter Lang. New York: NY.

Lazic, D. (2013). News Analysis of the Fukushima Accident: Lack of Information Disclosure, Radiation Fears and Accountability Issues. Journal of Contemporary Eastern Asia, 12(2), 19-34.

Lövbrand, E., Stripple, J., \& Wiman, B. (2009). Earth System governmentality: Reflections on science in the Anthropocene. Global Environmental Change, 19(1), 7-13. http://dx.doi.org/10.1016/j.gloenvcha.2008.10.002

Lubell, M. (2002). Environmental activism as collective action. Environment and Behavior, 34(4), 431-454. http://dx.doi.org/10.1177/00116502034004002

McCombs, M. (2005). A look at agenda-setting: Past, present and future. Journalism studies, 6(4), 543-557. http://dx.doi.org/10.1080/14616700500250438

McKenzie-Mohr, D., \& Smith, W. (1999). Fostering Sustainable Behavior: An Introduction to Community-Based Social Marketing. New Society Publishers, Gabriola Island, BC.

McPhearson \& Tidball (2013). Disturbances in Urban Social-Ecological Systems: Niche Opportunities for Environmental Education. In M. Krasny and J. Dillon (Eds). Trading Zones in Environmental Education. pp. 193-230. New York: NY. Peter Lang.

Morgan, M. G., \& Lave, L. (1990). Ethical Considerations in Risk Communication Practice and Research. Risk Analysis, 10(3), 355-358. http://dx.doi.org/10.1111/j.1539-6924.1990.tb00515.x 
Moser, S. C., \& Dilling, L. (2007). Creating a climate for change. Communicating Climate Change and Facilitating Social Change. Cambridge University Press. New York. US. http://dx.doi.org/10.1017/CBO9780511535871.035

Nisbet, M. (2012). Why the Future of Nuclear Energy May Depend on Media Coverage [Blog post]. Retrieved from http://bigthink.com/age-of-engagement/why-the-future-of-nuclear-energy-may-depend-on-media-coverage

Nordlund, A. M., \& Garvill, J. (2002). Value structures behind proenvironmental behavior. Environment and Behavior, 34(6), 740-756. http://dx.doi.org/10.1177/001391602237244

Rausch, A. (2012). Framing a Catastrophe: Portrayal of the 3.11 Disaster by a Local Japanese Newspaper. Electronic Journal of Contemporary Japanese studies. http://www.japanesestudies.org.uk/ejcjs/vol12/iss1/rausch.html.

Rogers, L. H. (1994). California freshwater shrimp project: An eco-action project with real life learning. San Rafael, CA: Dominican College. (ERIC Document Reproduction Service No. ED374963).

Sakaki, T., Okazaki, M., \& Matsuo, Y. (2010, April). Earthquake shakes Twitter users: real-time event detection by social sensors. In Proceedings of the 19th international conference on World wide web (pp. 851-860). ACM. http://dx.doi.org/10.1145/1772690.1772777

Seguin, C., Pelletier, L. G., \& Hunsley, J. (1999). Predicting Environmental Behaviors: The Influence of Self Determined Motivation and Information About Perceived Environmental Health Risks. Journal of Applied Social Psychology, 29(8), 1582-1604. http://dx.doi.org/10.1111/j.1559-1816.1999.tb02043.x

Skanavis C. (2004). Environment and Society: A relationship in continuous evolution, Kaleidoscope, Athens.

Skanavis, C., Koumouris, G. A., \& Petreniti, V. (2005). Public participation mechanisms in environmental disasters. Environmental management, 35(6), 821-837. http://dx.doi.org/10.1007/s00267-004-0120-z

Smith, K. (2013). Environmental hazards: assessing risk and reducing disaster. Routledge.

Stefanidis, A., Crooks, A., \& Radzikowski, J. (2013). Harvesting ambient geospatial information from social media feeds. GeoJournal, 78(2) 1-20. http://dx.doi.org/10.1007/s10708-011-9438-2

Thomson, R., Ito, N., Suda, H., Lin, F., Liu, Y., Hayasaka, R., ... \& Wang, Z. (2012). Trusting Tweets: The Fukushima Disaster and Information Source Credibility on Twitter. In Proceedings of the 9th International Conference on Information Systems for Crisis Response and Management. Retrieved from http://www.robthomo.com/wp-content/uploads/2012/04/Thomson_et_al_2012_Trusting_Tweets.pdf.

Uzzell, D. (2004). From local to global: A case of environmental hyperopia. UPDATE-The IHDP Newsletter, $4,4,6-7$.

Viswanathan, S. (June 21, 2010). How The Hindu covered the 1984 Bhopal calamity. The Hindu. Retrieved from www.thehindu.com

Vlek, P., \& Steg, L. (2004). Solid environmental policy needs valid environmental psychology. UPDATE-The IHDP Newsletter, 4, 11-13.

Walker, B., \& Salt, D. (2006). Resilience thinking: sustaining ecosystems and people in a changing world. Washington: Island Press.

\section{(cc) BY}

This work is licensed under a Creative Commons Attribution 3.0 License. 